\title{
Representative permeability types and their application in researching upper Oligocene sedimentary oil reservoir of ThT oil field
}

\section{- Tran Van Xuan}

Univerrsity of Technology, NVU-HCM

(Received on March $4^{\text {th }} 2015$, accepted on June $5^{\text {th }}$ 2015)

\section{ABSTRACT}

Permeability is the indispensable parameter in oil and gas reservoir studies. In fact of researching and operating on oil and gas fields worldwide, there are many types of permeability. Each permeability type has a specific characteristic according to the study purpose. In this article, the specific

characteristics of some typical permeability as gas permeability; water permeability, effective permeability; relative permeability ... will be analyzed, especially concern to the role of each permeability type in oil reservoir study to assisting researchers has an overview to orient their study.

Key works: Permeability, cut off value, mean value, relationship, HFU, cross plot, reservoir rock group.

\section{INTRODUCTION}

Brief introduction to the upper oligocene sedimentary reservoir of ThT oil field

ThT structure is located in the Northwestern region of block 09-1, outside the White Tiger oil field. On the tectonic map, this region belongs to north-west zone of the single inclined lifting of BachHo unit (Fig. 1). ThT structure was discovered in 2010 based on the interpretation results of $3 \mathrm{D}$ seismic data in the area of the less studied ones of block 09-1. According to the delineated area that has prospects in the upper oligocene and lower miocene sediments from the SH-11 to SH-5 seismic surfaces.

As at the date of 01.01.2014, on the ThT prospect there were a wild cat well THT-1X, one exploration well ThT-2X, one appraisal well THT-3XP, an early wells THT-4XP and two production wells (ThT-5P, 6P). According to the drilling results, the geological sections are mainly terrigenous sediments. 


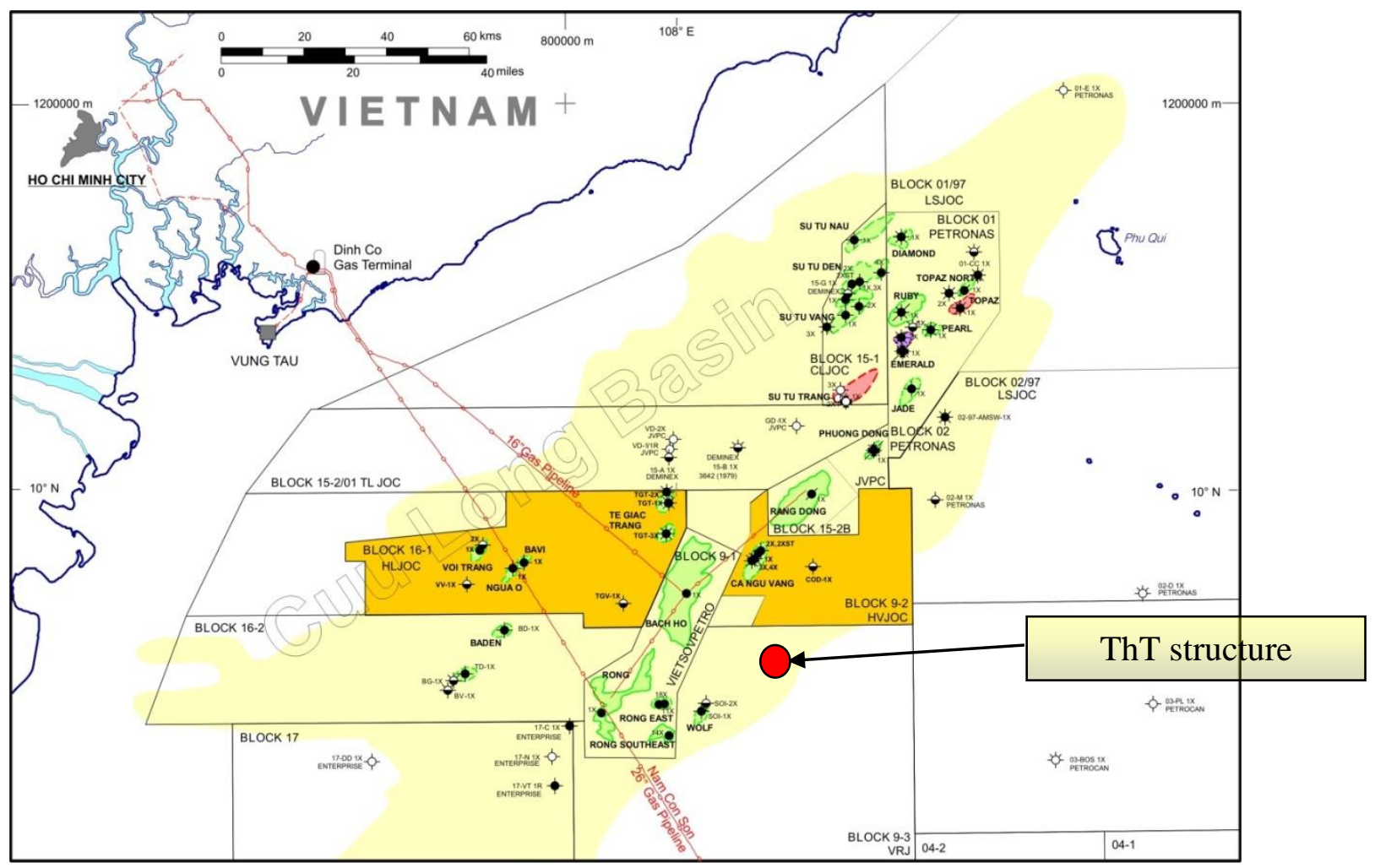

Fig 1. Location map of ThT structure

The reservoir sandstones in geological section of TraTan formation (upper Oligocene) is interbed with layers of argillite clay and contain moderate porosity and permeability. They are the prospects for oil and gas exploration in ThT structure.

Based on lithological composition, this formation can be divided into three parts.

In the upper part (from SH-7 to SH- 8), the sediments are mainly alternating layers of finegrained sandstone and shale with color changes from medium brown to dark brown. According to geophysic data of THT-1X well, the top part contains the reservoir at the depth of 3696-3493 m (3466-3408 m SSTVD) with porosities and oil saturation vary from 10 to $17 \%$ and from 35 to $52 \%$, respectively. The well test at the depth of approximately 3658-3493 m / m (3478-3322
SSVTD) through cone $12.7 \mathrm{~mm}$ delivered the oil and gas with the corresponding flow rate of 214 $\mathrm{m}^{3} /$ day and $51.4 \mathrm{Mm}^{3} /$ day; at the depth of approximately 3485-3408 m (3314-3241 SSVTD) through cone $15.86 \mathrm{~mm}$ received oil and gas with the corresponding flow rate of $230 \mathrm{~m}^{3}$ /day and $21 \mathrm{Mm}^{3} /$ day. At THT-2X wells, when operated the well test at I target at the depth around 3824-3756 m deep was getting gushing oil and natural gas, with corresponding flow rate of $90 \mathrm{~m}^{3}$ / day and $18.7 \mathrm{Mm}^{3} /$ day.

On the area of the ThT structure, due to all wells drilled only to SH-8 surface, hence the lithological characteristics of the stratigraphic sections from $\mathrm{SH}-8$ to the basement formation are determined in accordance with sections of wells in the north-west of White Tiger and TGT-1X wells on the Te Giac Trang structure [4]. 


\section{The research methodology for permeability}

Permeability is a measurement of the ability of a porous media to allow fluids to pass through it. There are many researchers have been interested in study permeability of sedimentary rock. French Engineer Henry Darcy, 1856, was the first scientist to describe the flow of water through sand filters for potable water supply and to built the law named Darcy's Law. Up to present date, Darcy's Law has still been used extensively in petroleum industry. Darcy's Law is built on the research base flow of single-phase fluid (water) and does not interact with porous media (sand). To apply Darcy's Law for oil reservoir with many different complex factors, the researchers have applied this law in specific circumstances.

\section{Gas permeability}

The expression for determining the permeability of a porous medium to gas is one different form to that of liquid. The reason is gas is compressible fluid whereas a liquid is just slightly one. When a gas flows toward the downstream end of a core sample, its pressure decreases, the gas expand, consequence its velocity will increase. The Darcy equation for ideal horizontal laminar flow of gas under steady state isothermal condition is expressed as follows:

$$
k_{\text {gas }}=\frac{2 \mu \mathrm{ZT} P_{b} L Q_{b}}{\mathrm{~A} T_{b}\left(P_{1}^{2}-P_{2}^{2}\right)}(1)
$$

where: Kgas= permeability to gas (D) $\mu=$ gas viscosity $(\mathrm{P})$
$\mathrm{Z}=$ mean gas compressibility factor

$\mathrm{T}=$ mean temperature of flowing gas $\left({ }^{\circ} \mathrm{F}\right)$

$\mathrm{P}_{\mathrm{b}}=$ base or atmospheric pressure (absolute atm)

$\mathrm{L}=$ length of sample $(\mathrm{cm})$

$\mathrm{Qb}=$ atmospheric gas flow rate $(\mathrm{cm} / \mathrm{s})$ at base pressure $\mathrm{Pb}$

$\mathrm{A}=$ cross sectional area of cylinder $\left(\mathrm{cm}^{2}\right)$

$\mathrm{T}_{\mathrm{b}}=$ base temperature (ambient)

$\mathrm{P}_{1}, \mathrm{P}_{2}=$ upstream and downstream absolute pressure respectively (atm),

If the base temperature equals, the mean temperature of the flowing gas and $\mathrm{Z}$ is taken as the unity, which is approximately true for nitrogen under typical operating ambient conditions. And since core pressure drop $\Delta \mathrm{P}=$ $\mathrm{P}_{1}-\mathrm{P}_{2}$; and core mean pressure $\mathrm{P}_{\mathrm{m}}=\left(\mathrm{P}_{1}-\mathrm{P}_{2}\right) / 2$ then the equation (1) can be reduced to the less unwieldy expression

$$
k_{g a s}=\frac{\mu P_{b} L Q_{b}}{\mathrm{~A} \Delta \mathrm{P} P_{m}}(2)
$$

Klinkenberg L J, 1941 in his study presented that the phenomenon of gas having velocity at the pore wall caused by a molecular flow, has its own flow regime. This type of velocity is known as "slip velocity" or as "Knudsen flow". Hence the terminology Permeability Klinkenberg $\mathrm{K}_{\mathrm{L}}$ can be applied and determined by measuring $\mathrm{Kg}$ values with different core mean pressure $\mathrm{P}_{\mathrm{m}}$. $\mathrm{K}_{\mathrm{L}}$ is determined from the equation $\mathrm{K}_{\mathrm{g}}=\mathrm{f}(1 / \mathrm{Pm})$.

\section{Trang 48}


On the basis of the hydrocarbon potential of the collective upper oligocene formation, this target should be of particular interest, the authors apply for research results of petrographic characteristics of sediments on the basis of core analysis to describe the core samples with initial estimates of the rock type and to determine the characteristics of the architecture, composed of them; detailed study by polarization microscopy on the petrographic thin sections to determine the mineral composition, architecture and the level of secondary alteration of the rocks; Roentgen diffraction analysis; analysis of grain size and carbonate particles (for sedimentary rocks); architectural study of the porous media on thin section by color plastic injection to define the shape, size, spatial morphology of different porosity types..in order to research and evaluate the representative permeability types.

\section{METARIALS AND METHODS}

\section{Samples}

Core samples were taken from the 02 exploration wells and cuttings from 3 wells. Total cores is $32 \mathrm{~m}$ samples, recovery factor is $100 \%$ (32 m) (Table 1).

Table 1. Coring amount of ThT oilfield

\begin{tabular}{|c|c|c|c|c|c|}
\hline \multirow{2}{*}{ Wells } & Interval of coring & Length of coring & \multicolumn{2}{|c|}{ Recovery } & $\begin{array}{c}\text { Sedimentary } \\
\text { formation }\end{array}$ \\
\cline { 2 - 5 } & $\mathrm{m}$ & $\mathrm{m}$ & $\mathrm{m}$ & $\%$ & \\
\hline \multirow{2}{*}{ ThT-1X } & $3300.0-3308.0$ & 8.0 & 8.0 & 100 & Lower Miocene \\
\cline { 2 - 5 } & $3514.0-3522.0$ & 8.0 & 8.0 & 100 & Upper Oligocene \\
\hline \multirow{2}{*}{ ThT-2X } & $3675.0-3683.0$ & 8.0 & 8.0 & 100 & Upper Oligocene \\
\cline { 2 - 5 } & $3854.0-3862.0$ & 8.0 & 8.0 & 100 & Upper Oligocene \\
\hline
\end{tabular}

Physical characteristics of the production formation and seal determined by core analysis

Determination of matrix density and dry density $\operatorname{rock}(\rho)$;

Determination of open porosity by oil and helium saturation $(\varphi 0)$;

Determination of gas permeability $(\mathrm{Kg})$;
Determination of residual water saturation (Swr);

Determine the total amount of natural radioactivity of rocks $(\Sigma q)$;

Determine the duration of the sonic wave $(\Delta \mathrm{T})$;

Define formation factor $(\mathrm{FF})$;

Determine the resistivityindex (RI).

Table 2. The amount of physical properties study in ThT structure

\begin{tabular}{|c|c|c|c|c|c|c|c|c|}
\hline \multirow{2}{*}{ The formation } & \multicolumn{7}{|c|}{ Amount and physical properties } \\
\cline { 2 - 10 } & $\varphi$ & $\rho$ & $\mathrm{Kg}$ & $\mathrm{Sw}$ & $\mathrm{FF}$ & $\mathrm{RI}$ & $\Sigma \mathrm{q}$ & $\Delta \mathrm{T}$ \\
\hline Upper oligocene & 130 & 146 & 135 & 130 & 130 & 130 & 199 & 130 \\
\hline
\end{tabular}




\section{Rock physical parameters}

Matrix density is determined by the Picnometo method.

The dry density is determined by hydrostatic balance method in liquid form.

The opening porosity is determined by water saturation and helium method.

Gas permeability is determined by steady flow method.

Residual water saturation is determined by means of semi-permeable membrane.

The duration of the sonic wave and the resistivity of the rock is determined at surface conditions.

\section{RESULTS}

Distribution curves of the total amount of natural radioactive, matrix density, open porosity, gas permeability and residual water saturation of upper oligocene formation are given in Fig. 2-8.

Total natural radioactivity: Change in approximately 1.1 to 4.42 pg.eq. Ra / g (average $\sum q=2.39$ pg.eq. $\mathrm{Ra} / \mathrm{g}$ ) according to the results of analysis of 199 samples.

Matrix density: Change in about 2.48 to 2.89 $\mathrm{g} / \mathrm{cm}^{3}$ (average of $\rho=2.65 \mathrm{~g} / \mathrm{cm}^{3}$ ) according to the analysis results from 146 samples.
Open porosity: Change in the range from 2.28 to $18.12 \%$ (average $\varphi=12.59 \%$ ) according to the analysis results from 130 samples.

Gas permeability: Ranged from 0.02 to 73.46 $\mathrm{mD}$ (average $\mathrm{Kg}=3.11 \mathrm{mD}$ ) by the analysis of 135 samples.

Residual water saturation: Change in the range 41.81 to $98.66 \%$ (average $\mathrm{Sw}=81.1 \%$ $\mathrm{Sw}$ ) according to the analysis results from 130 samples.

\section{Correcting the results of the physical parameter relationships}

The graphs and equations relationship between physical parameters of formation rocks

$\Phi=1.16 \mathrm{Ln}(\mathrm{Kg})+13.9 ; \mathrm{R}^{2}=0.51 ; \mathrm{N}=112$ samples;

$\mathrm{Sw}=77.34 \mathrm{Kg}^{-0,12} ; \mathrm{R}^{2}=0.72 ; \mathrm{N}=130$ samples;

$\Phi=-2.67 \eta+15,6 ; R^{2}=0.14 ; \mathrm{N}=60$ samples;

$\Delta \mathrm{T}=10.21 \Phi+155.03 ; \mathrm{R}^{2}=0.91 ; \mathrm{N}=128$ samples;

$\mathrm{FF}=2.97 \Phi^{-1,31} ; \mathrm{R}^{2}=0.91 ; \mathrm{N}=130$ samples;

$\mathrm{RI}=1.31 \mathrm{Sw}^{-2,18} ; \mathrm{R}^{2}=0.82 ; \mathrm{N}=130$ samples.

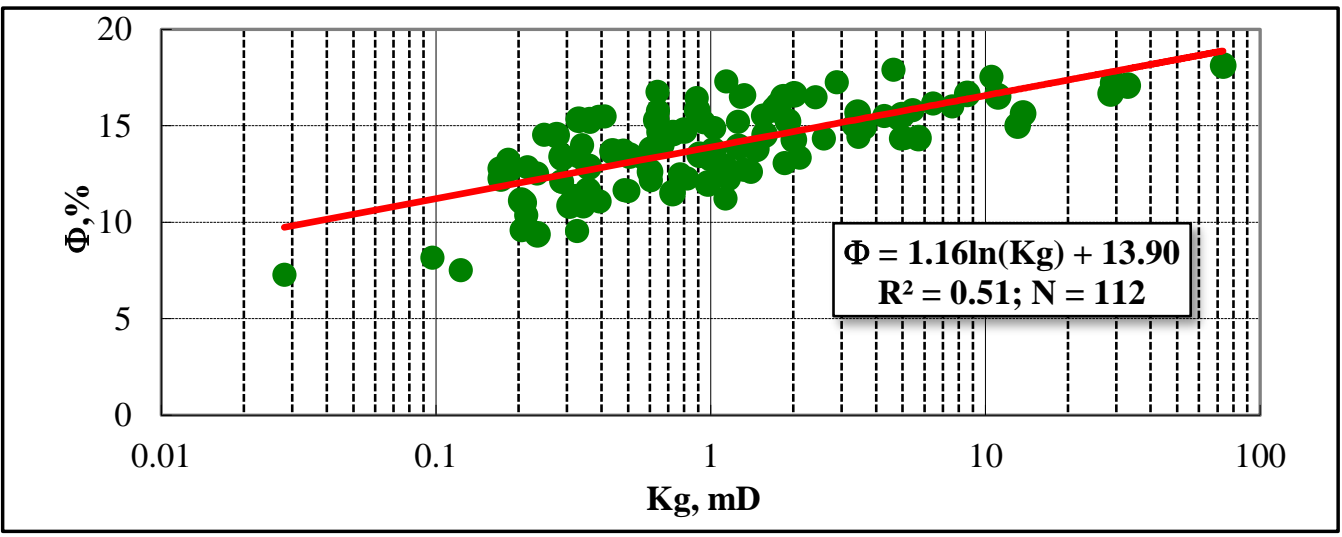

Fig 2 . The relationship between porosity and gas permeability

\section{Trang 50}




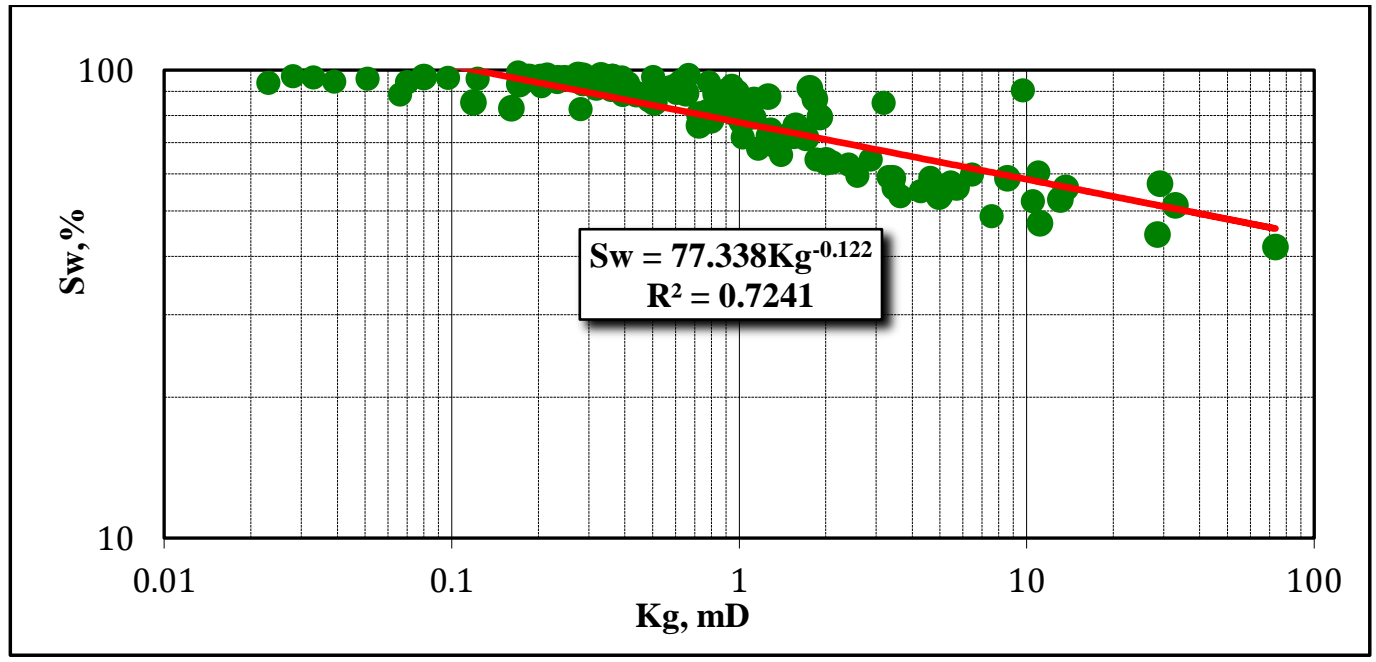

Fig 3. The relationship between residual water saturation and gas permeability

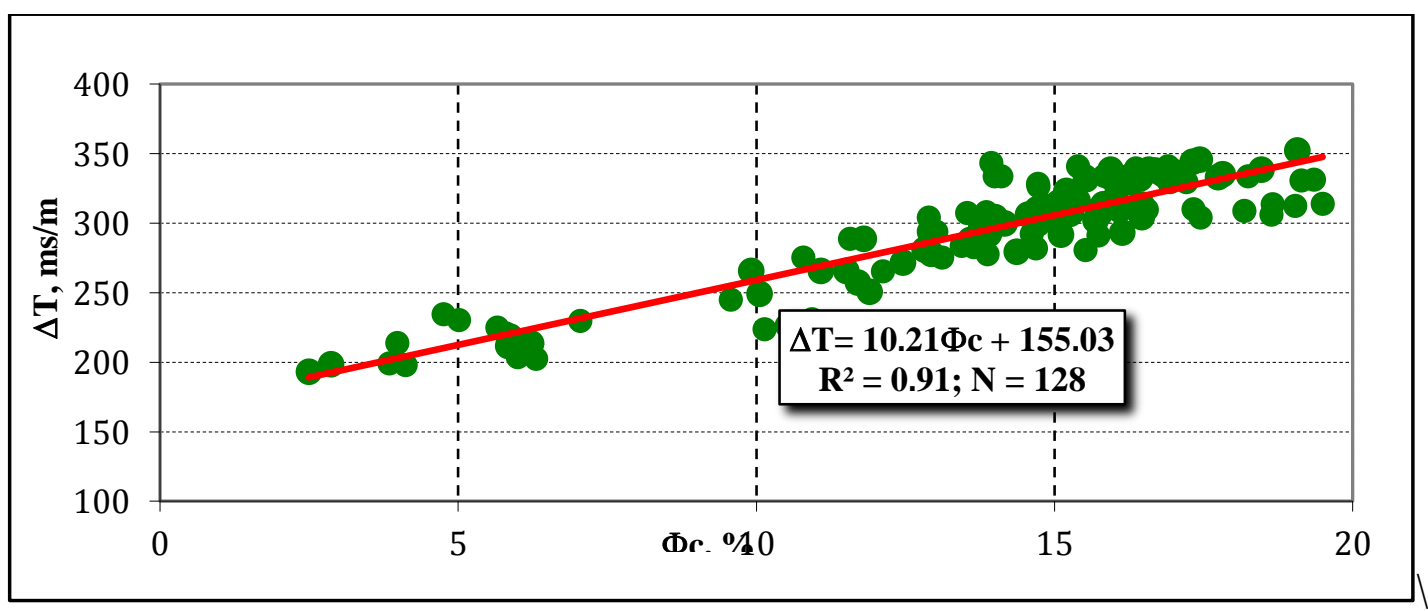

Fig 4. The relationship between duration of the sonic wave and porosity

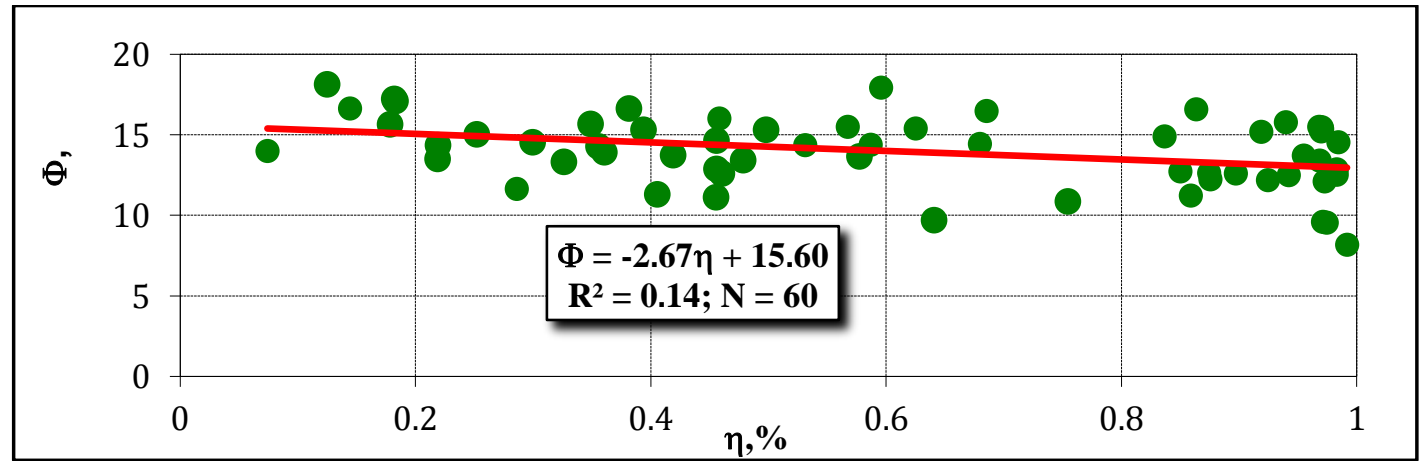


Fig 5. The relationship between porosity and $\eta$

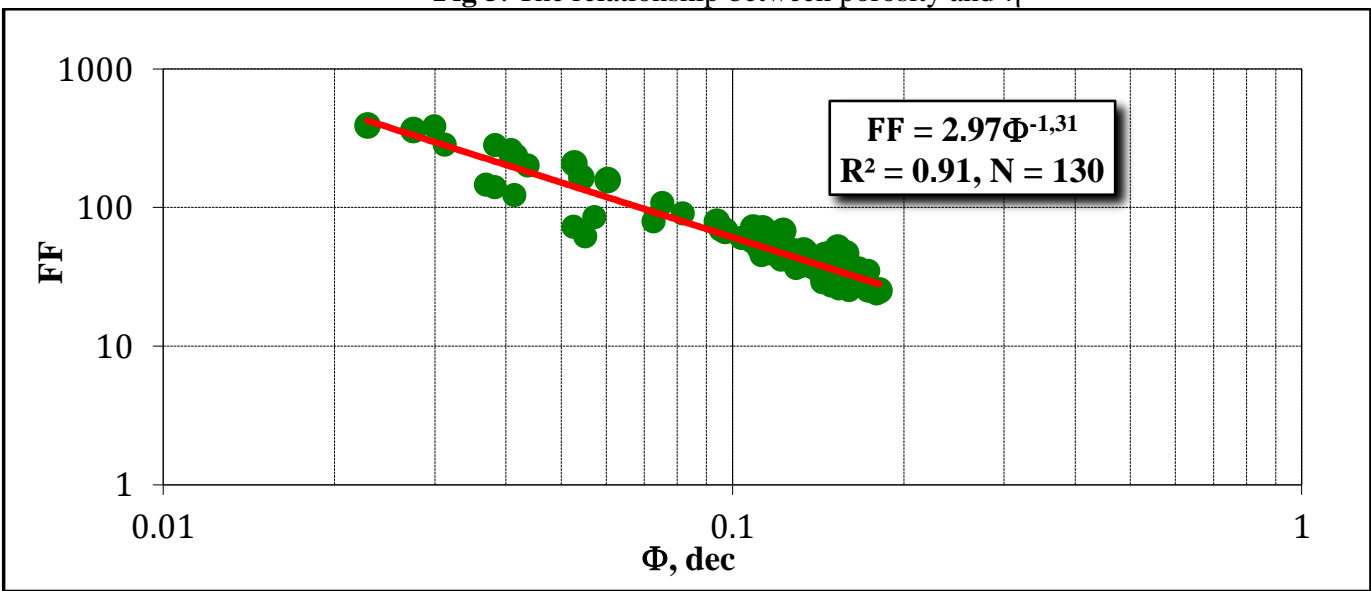

Fig 6. The relationship between formation factor and porosity

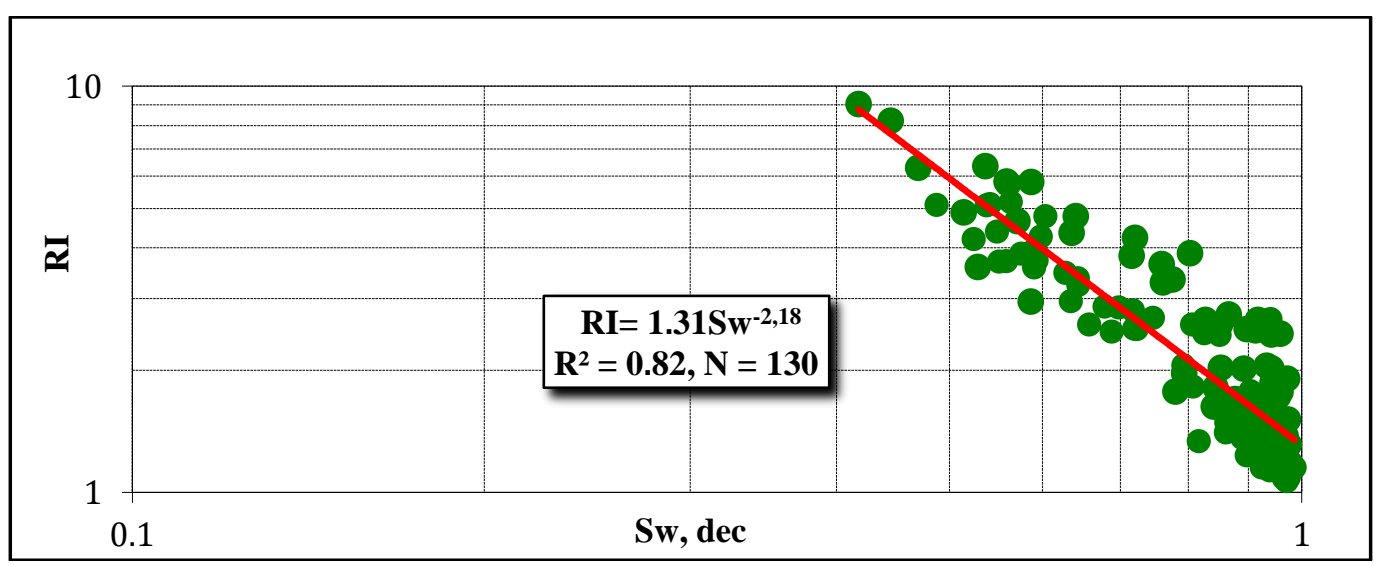

Fig 7. The relationship between resistivity index and water saturation

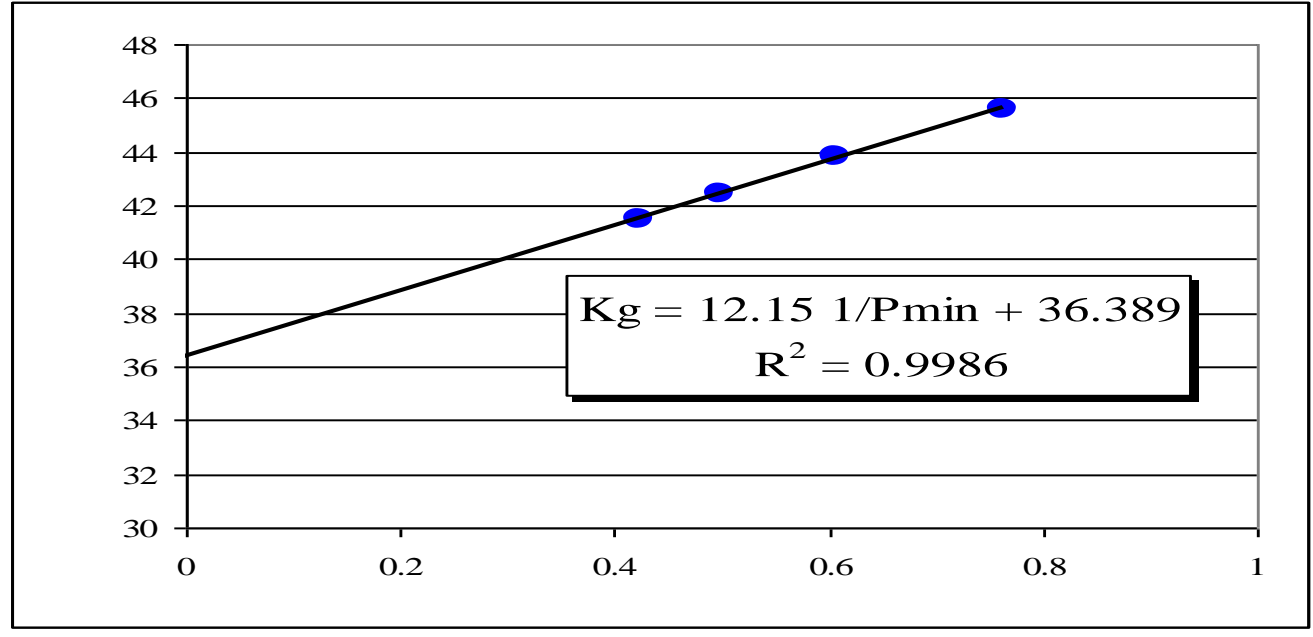

Fig 8. The relationship between gas permeability and core mean pressure $\mathrm{P}_{\mathrm{m}}$

\section{Trang 52}


Based on study results of the relationship between gas permeability $\mathrm{Kg}$ and core mean pressure $\mathrm{Pm}$, the $\mathrm{K}_{\mathrm{L}}$ and the Klinkenberg factors are determined $\mathrm{K}_{\mathrm{L}}=36.389 \mathrm{md} ; \quad \mathrm{b}_{\mathrm{k}}=$ $12.15 / 36.389=0.334 \mathrm{at}=4.908 \mathrm{psi}$, respectively (Fig 8).

\section{Absolute (water) rermeability, Ks}

When the porous medium is saturate with $100 \%$ water, the permeability measured in this case is the permeability to water or the water permeability. Some authors also call the absolute permeability.

$$
K s=\frac{q_{w} \mu_{w} L}{A \Delta P_{w}} \text { withSw }=100 \%
$$

\section{Effective and relative permeability}

The effective and relative permeability definitions are applied when the pores contain more than one phase (the displacing and the displaced phases) and no further production of the displaced phase. The permeability measured in this case is the effective permeability to the displacing phase.

Effective permeability to oil, Ko

$$
K o=\frac{q_{o} \mu_{o} L}{A \Delta P_{o}}, \text { withSw }=\text { Srw }
$$

Effective permeability to water, $\mathrm{Kw}$

$$
K w=\frac{q_{w} \mu_{w} L}{A \Delta P_{w}}, \text { withSo }=\text { Sro }
$$

Relative permeability to oil, Kroi= Koi/Ks (6) Relative permeability to water, Krwi=Kwi/Ks (7) where Koi, Kwi: effective permeability to oil and water at Swi

The transmissibility (thickness* permeability)

The transmissibility is determined from drawdown well test data by using semilog plot graph (Figure 9). If the effective thickness of the zone is known, the effective permeability is calculated by using the following formula.

$$
k=-162.6 \frac{q B \mu}{m h}
$$

Where $\mathrm{k}$ : effective permeability, md

q: flow rate, STB/D

$B$ : formation volume factor, $\mathrm{RB} / \mathrm{STB}$

$\mu$ : viscosity, $\mathrm{cP}$

$\mathrm{h}$ : effective formation thickness, $\mathrm{ft}$

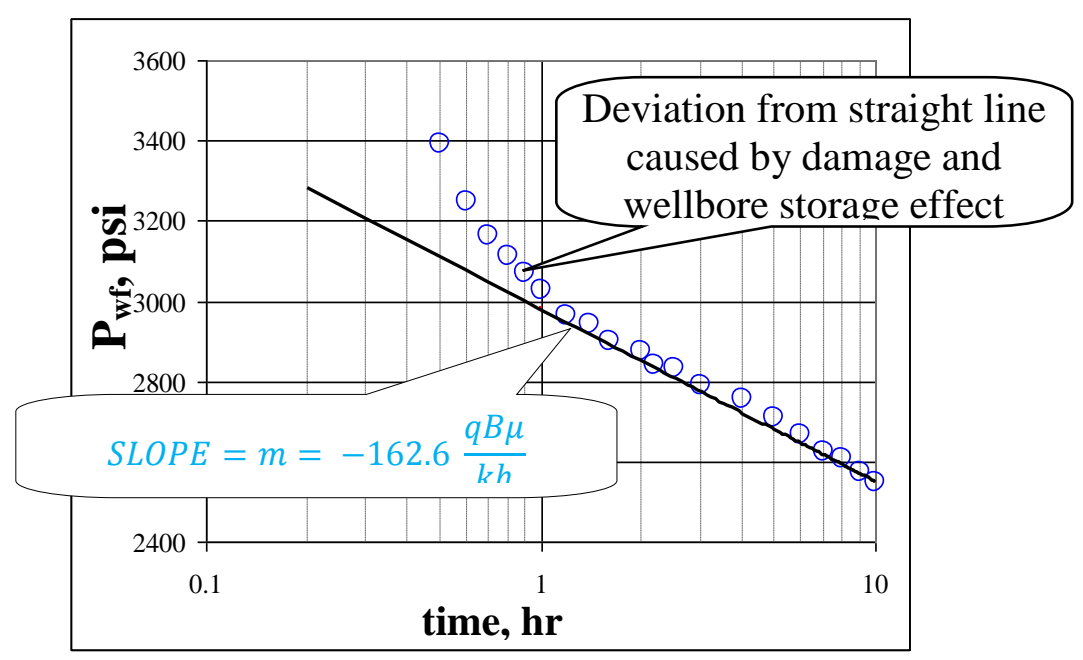

Fig 9. Semilog plot of pressure drawdown data for a well with wellbore storage and skin effect 
Permeability application in sedimentary oil reservoir research

Evaluating the cutoff values [5]

It is necessary to determine the net-pay permeability cut-off values which will be applied to estimate oil reserves. The value of the permeability cutoff can be determined from the relationship between the gas permeability and the porosity cutoff which in turn they are determined from the relationship between the porosity and the effective porosity.
Effective porosity is calculated by the equation:

$$
\emptyset_{\text {eff }}=\emptyset\left(1-S_{w r}\right)
$$

Where: $\Phi$ eff, $\Phi$ : effective porosity and open porosity respectively; Swr: residual water saturation.

The processing to determine the cutoff value of permeability is presented in Fig. $10-11$.

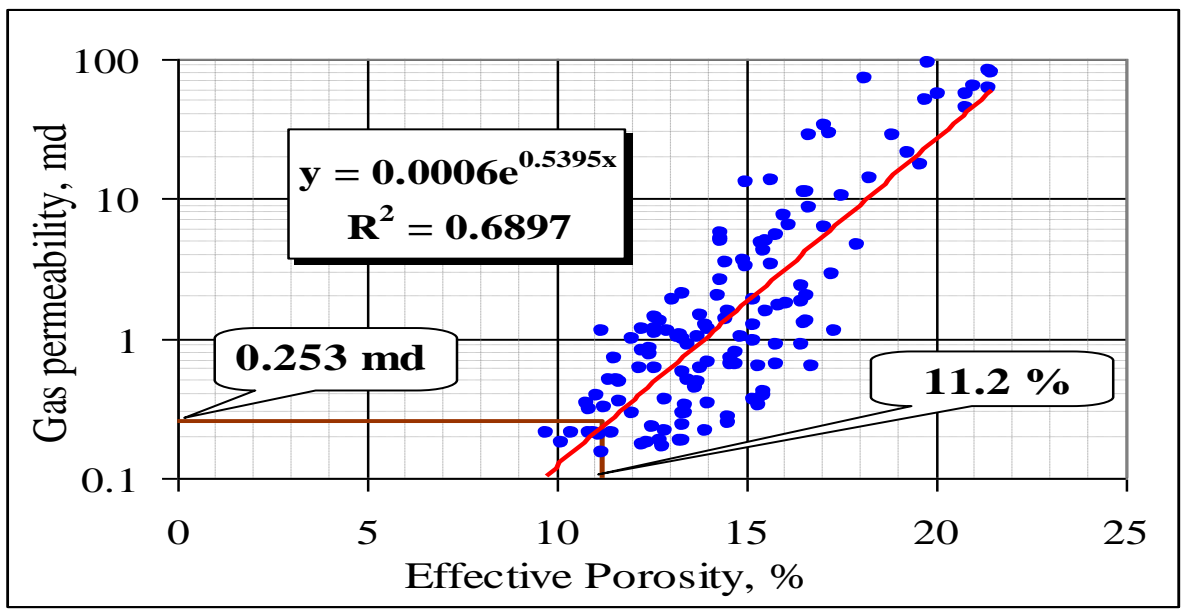

Fig 10. The relationship between the effective porosity and the open porosity

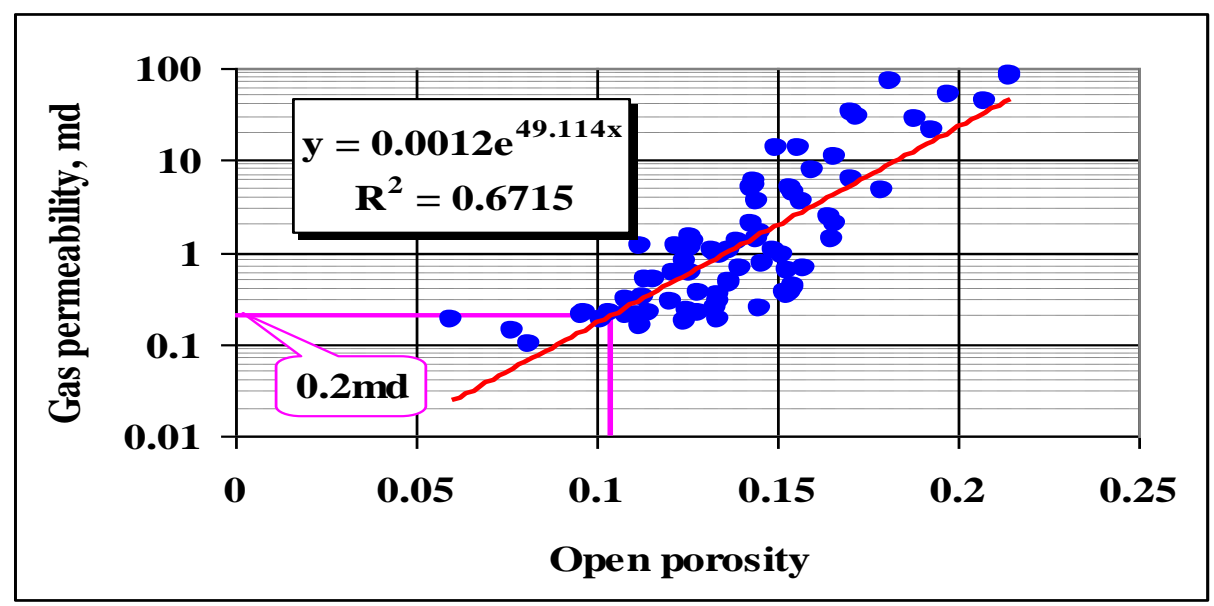

Fig 11.The relationship between the gas permeability and the effective porosity

\section{Trang 54}


Evaluating the reservoir quality index [1]

In case analyzing a reservoir with a high degree of heterogeneity, it's needed to divide it into different groups of rocks. Some researchers have combined the rocks with the same Reservoir

Quality Index (RQI) into a group and call Hydraulic Flow Units (HFU) in which RQI is calculated by the equation 10 hereafter:

$$
R Q I=0.0314 \sqrt{\frac{k}{\emptyset_{e}}}
$$

where k: gas permeability; $\varphi_{\mathrm{e}}$ : effective
In this case, the heterogeneous reservoirs are divided into groups based on analysis in average grain size [2].

The different results between two methods, with the same set of data are illustrated in Fig. 12 -15.

The research results show that the divided rock method based on the mean grain size have high manners. porosity.

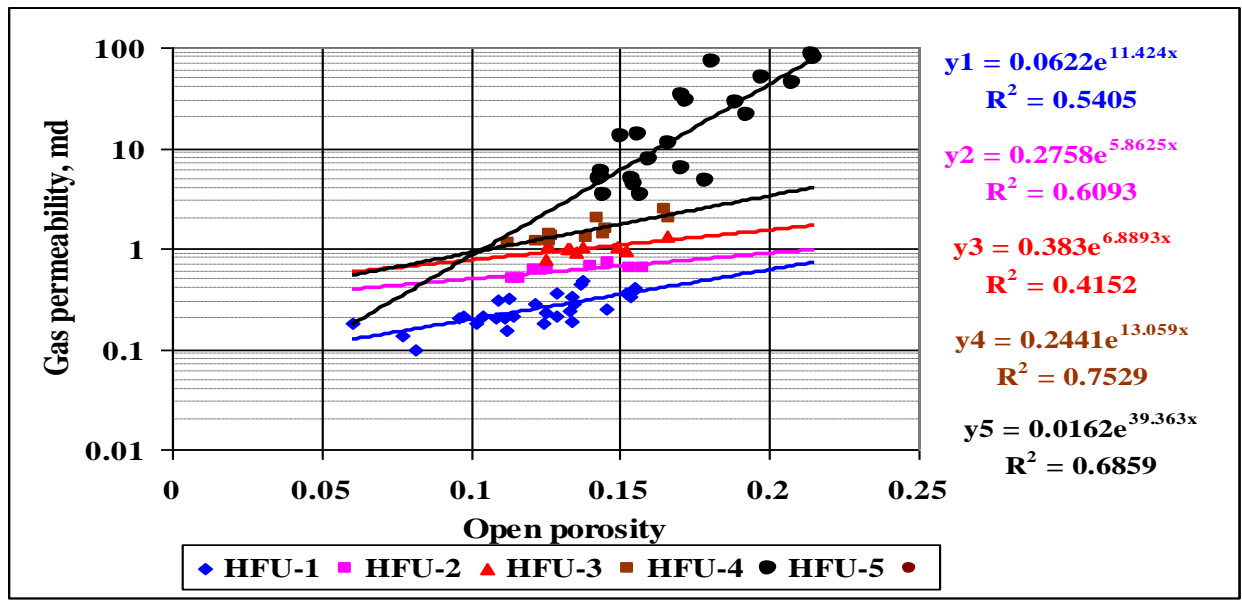

Figure 12. Gas permeability and open porosity cross plot for different HFU

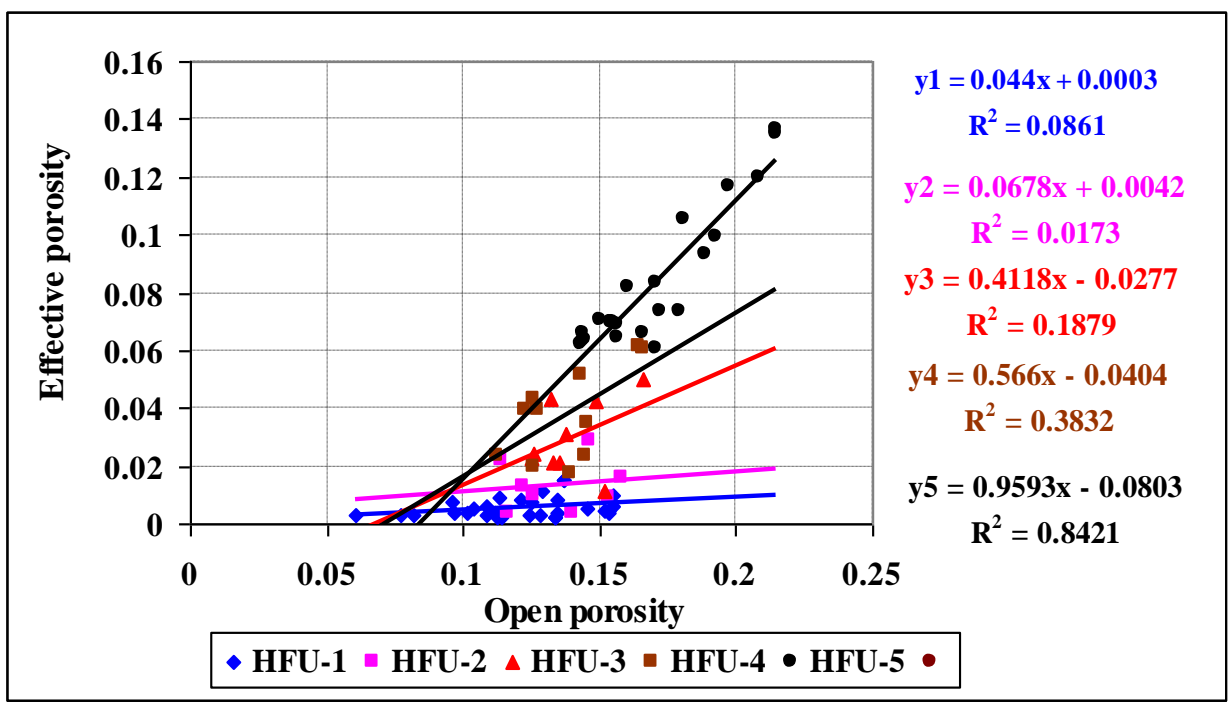


Fig 13. Effective porosity and open porosity cross plot for different HFU

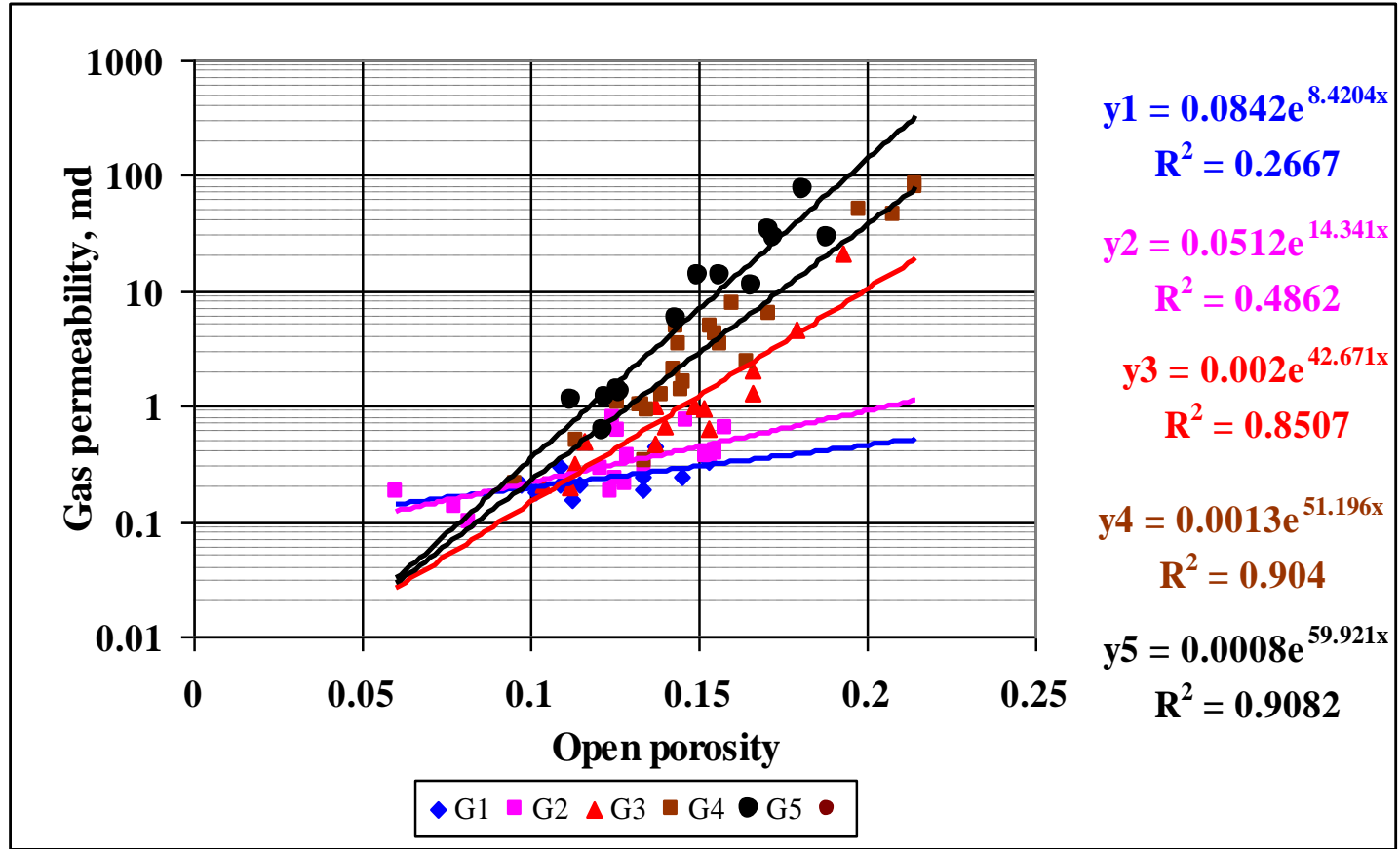

Fig 14. Gas permeability and open porosity cross plot for different groups

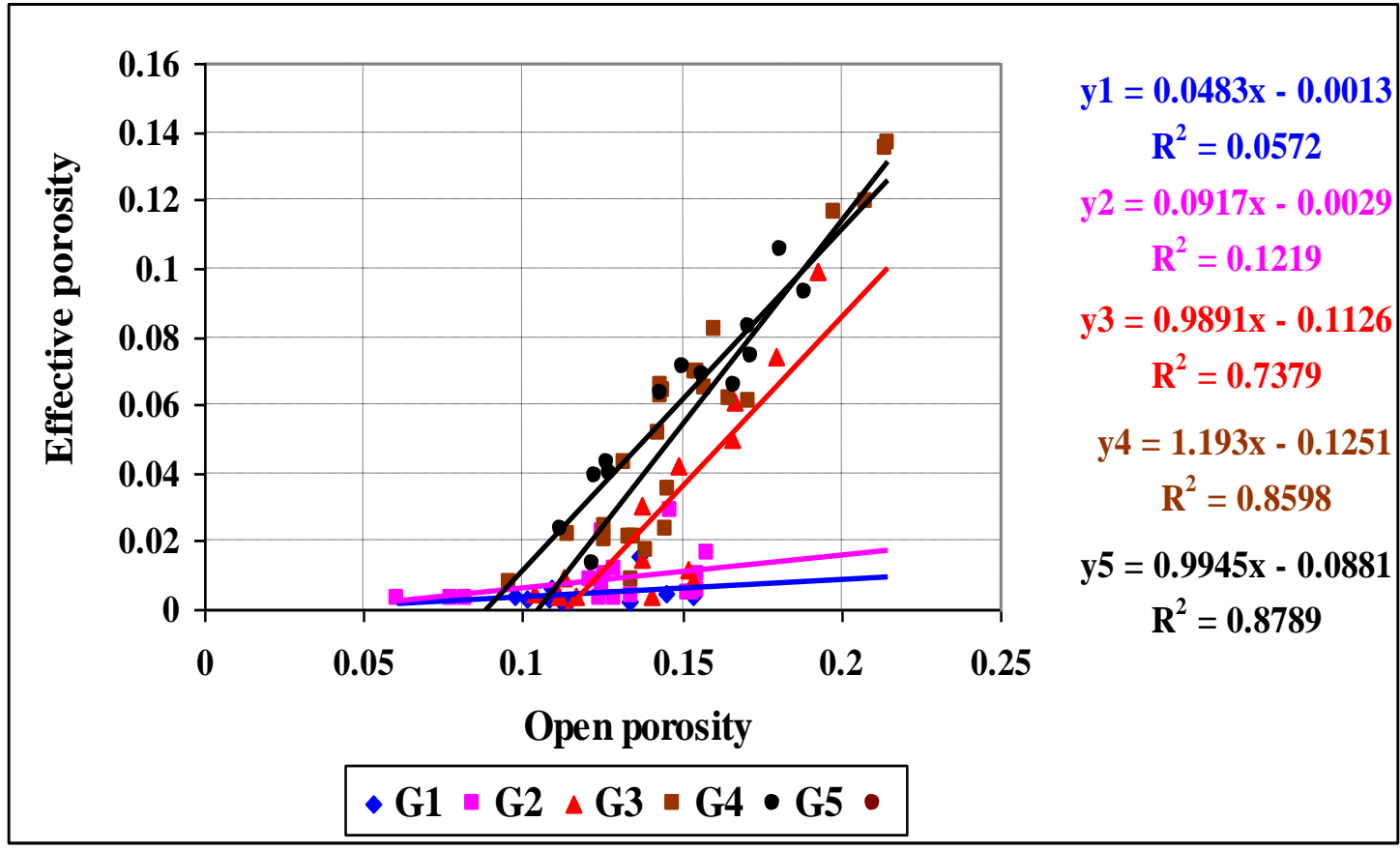

Fig 15. Effective porosity and open porosity cross plot for different groups 
Using permeability and relative permeability as input data to a reservoir simulator

Petrophysic parameters such as porosity, netto-gross ratios, and three diagonal components of the permeability tensor are input to Eclipse software (a Reservoir Simulation software). The general syntax is defined in the basic data input example, one value for each cell. Due to permeability varies with $\mathrm{x}$ in the interval $(\mathrm{x} 0, \mathrm{x} 1)$, it is possible to define a constant representative permeability, $\mathrm{K}=\mathrm{K}^{*}$, that flow between $\mathrm{x} 0$ and $\mathrm{x} 1$ is the same if the actual variation $\mathrm{K}(\mathrm{x})$ replaced with the constant $\mathrm{K}^{*}$. This is one of solution using permeability in Eclipse [3].

As mentioned above, there are many types of permeability, and apparently gas permeability could not been chosen as input data for Eclipse (including Klinkenberg permeability). In generally only relative permeability is used as input data for Eclipse.

\section{DISCUSSION}

Our results showed that the upper oligocene sedimentary rocks have average porosity, low gas permeability, average residual water saturation. This proves that oligocene sedimentary rocks in the ThT structure contain potentially oil reserves on moderate classification. The low level of correlation between the porosity and the permeability shows the formation of various derived permeability types formed by different origins as well as the physical characteristics and lithology complication, interbed by multiple shale layers. Hence researchers need to divide the heterogeneous sediment reservoir rocks in to separate groups.

\section{CONCLUSION AND RECOMMENDATION}

There are many types of permeability. Each type of permeability is determined by different methods which are applied for different purposes. The users need to distinguish the reasonable type of permeability.

When studying the relationship between the physical parameters of sedimentary rocks with high degree of heterogeneity, it is needed to divide this sequence rock into groups. Using the mean grain size to divide sedimentary rock into different groups has high practical significance.

The permeability used for the construction of models in simulating the hydrodynamic flow in the reservoir needs to be carefully studied.

The results represent the type of representative permeability, combined with data such as structural maps, integrated correlation of seismic reflection surfaces and productivity reservoir by well log data. The study of the geophysical properties of reservoir rock by core analysis, well test results, flowing performance, the PLT and production data allows operators to determine the fluid contacts, oil and gas reserves classification and estimation of upper oligocene reservoir.

ACKNOWLEDGEMENTS: This research is funded by Vietnam National University Ho Chi Minh City (VNU-HCM) under grant number B2015-20-06. 


\section{Loại hình độ thấm đại diện và ứng dụng nghiên cứu thân dầu trong trầm tích Oligoxen trên mỏ ThT}

- Trần Văn Xuân

Trường Đại học Bách Khoa, ĐHQG-HCM

\section{TÓM TÁT}

Độ thấm là tham số tối trọng trong nghiên cứu các mỏ dầu khí. Thực tiễn nghiên cứu, điều hành các mỏ dầu khí trên thế giới cho thấy tồn tại rất nhiều loại hình độ thấm. Mỗi loại độ thấm có một đặc trưng riêng biệt, phụ thuộc vào phương thức nghiên cứu, xác định. Trong bài báo này,

đặc trung của một số độ thấm điển hình như độ thấm khí, độ thấm của nước, độ thấm hiệu dụng, độ thấm tương đối sẽ được phân tích, đặc biệt chú trọng đến vai trò của từng loại độ thấm trong định hướng tổng quan cho những người làm công tác nghiên cứu liên quan.

Từ khóa: Độ thấm, giá trị tới hạn, giá trị trung bình, mối tương quan, đơn nguyên dòng thủy lực (HFU), đồ thị quan hệ, nhóm đá tầng chứa.

\section{REFERENCES}

[1]. A. D'Windt, Reservoir zonation and permeability estimation: a Bayesian approach, Annual Logging Symposium held in Austin, Texas, United States, June, 3-6 (2007).

[2]. F. Robert, Petrology of sedimentary rocks, Department of Geological Sciences, the University of Texas at Austin ( 2002).

[3]. P. Øystein, Basics of reservoir simulation with the eclipse reservoir simulator, Dept. Of Mathematics, University of Bergen (2006).
[4]. NIPI, Vietsovpetro, Internal reports (confidential) (2014).

[5]. T.D. Lan, T.T. Hung, Common permeability types and their application in researching sedimentary oil reservoir, The $8^{\text {th }}$ international conference on earth resources technology (2014). 